\title{
AN EVALUATION OF DISPUTE RESOLUTION IN BOTSWANA PUBLIC SECTOR
}

\author{
Theophilus TSHUKUDU*
}

\begin{abstract}
This paper aimed at scrutinizing how Botswana (Democratic State) a politically stable country for the first time since independence terminated contract for essential services section in Government abruptly, due to conditional salary increase of 5\% increase, hence Trade Unions proposing an increase from 16\% to $13.8 \%$, this was during Lt General lan Khama Seretse Khama's presidency. Failing to reach consensus, employees resorted to national strike which took eight weeks. "Ignorance of the law excuses not" and "ignorance of the law excuses no one" respectively; essential services employees, in terms of the Trade Dispute Act 2003, Cap 28: 02, (Laws of Botswana) every party to a dispute of interest has the right to strike or lockout if all the requisites of a lawful strike prescribed by the Act have been met. Even though every employee has the right to strike, it was argued that the industrial action by some of the employees was unlawful as they are classified as essential service employees. Therefore, the above statement abrupt essential services workers to strike, despite employee's grievances. In this scenario, the unions have to be blamed for not assisting the essential workers to understand the repercussion of (strike) consequences of crossing the law's path "ignorance of the law excuses not" and "ignorance of the law excuses no one" respectively.
\end{abstract}

Keywords: Botswana public service; dispute resolution; evaluation

DOI: 10.53373 / REDS.2021.52.3.034

\section{INTRODUCTION}

Botswana as Africa's oldest democracy is known to cherish the good values of tolerance that advocates virtues such as freedom of association (hence citizens free to join trade unions). Le Roux \& Cohen, (2016) States that in 2011 for the first in the history of Botswana, public officers embarked on unprecedented industrial actions happened which lasted for almost two months. Almost 3000 essential workers were collectively dismissed without hearing due to these consequences for partaking in an illegal strike and failing to comply with a strike interdict and various ultimatums to return to work public. Good, K. (2017). The strike by public-sector unions ('BOFEPUSU') in 2011, was also motivated by inadequate pay and conditions: the workers had not had a salary increase for three years, and working conditions in general, and especially for such groups as nurses combating HIV/AIDS, were reportedly poor. Salamon, (2000) cited in Motshegwa \&

* Department of Management, Faculty of Business, University of Botswana. 
Bodilenyane (2012) argued that a court that intervenes in an industrial conflict cannot be 'neutral', it will take one side or the other, and generally in doing so will add the weight of 'legal right' to the management side. According to Diamond, 1999 cited in Motshegwa \& Bodilenyane (2012) Democracy has to do with how government, interest group leaders exercise their power-not just their promise to democracy in opinions, but their ability to bargain with one another, form coalitions, mobilize public support and respond to public pressures and preferences. In 2020 public servant and their representatives unions were irked by the decisions by government to defer salary increment to public sector citing the challenges of corona virus. Public Sector and Trade unions were not consulted as there is no consultative forum such as public bargaining council. Even though the government made an announcement that public servants will get their back pays after the end of state emergency ( 6 months). These acts unilateralism by the government has rendered bargaining council totally nonexistent. This then shows that trade unions together with employees will always be in a weaker position of negotiating and the government can continue making unilateral and yet unpopular decisions that directly affects the welfare of the public service. This then now questions the democratic credentials of Botswana as a stable country.

\section{Public sector}

According to (Hope, 1995), the public sector is the largest organization in Botswana, it comprises Central and local government including parastatal institutions. It is the major sector in Botswana in terms of breadth of services delivered; numbers of people served; regional distribution of services provided; assets and expenditures under its management; and number of employees The country's public sector comprises central and local government together with parastatal institutions. Public Service rests with the Directorate of Public Service Management (DPSM) which is within the Office of the President.

\section{Trade Union in Botswana}

The participation of trade unions is, however, not very significant in terms of their ability to influence government decisions and/or policies particularly since their role is advisory and consequently, the government is not bound to accept any of its views or propositions in those forums (Friedrich Ebert Foundation 2008:31 cited in Molokwane, (2019). Unions encourage employees to be productive and adhere to acceptable performance standards at work. The tensions between the union representatives and government have at numerous times reached courts of laws. One notable example was in 2017 when the unions challenged their derecognition by a government within the bargaining council.

\section{Bargaining Council}

The presence of a Bargaining Council even though very important there may be some deadlocks when the dialogue between workers and employers is characterized 
by the reluctance on the part of the parties to compromise (Smithsen, 2009). The public strike of 2011 and the endorsement of the opposition Umbrella for Democratic Change in 2014 elections are some of the examples that collective voices are viewed as important for workers to pressure the government to improve their working conditions. With a non-functional Public Service Bargaining Council, the federations have always offered a glimmer of hope to workers as they continue engaging the government on various salary increment and other issues. According Tshukudu (2020), Since Botswana Public Service Bargaining Council (BPSB) inception, it has been ridden by problems, with labour and other commentators observing that government is dragging its feet to start the bargaining council to frustrate unions. The other major problem was non-adherence to Collective Agreement by President Khama whereby He addressed collective bargaining issues such as salary increment during his Kgotla (traditional gatherings) meetings.

\section{The unlawful court cases}

Motshegwa \& Bodilenyane (2012) distresses that "It is quite disturbing to realize that in a democratic state like Botswana the government can just act outside its mandate even though judges should be the final arbiters in disputes. One would expect the judicial system to have exercised their restraint to prevent the abuse of power by the state. However, due to judicial impartiality, the striking workers were not given an opportunity by the courts to defend themselves as to why they did not obey the Court Order. Indeed this was observed by Salamon (2000) cited in Motshegwa \& Bodilenyane 2012) who argued that a court that intervenes in an industrial conflict cannot be 'neutral', it will take one side or the other, and generally in doing so will add the weight of 'legal right' to the management side.

\section{PROBLEM STATEMENT}

Botswana as a democratic country allows citizens and organizations such as trade unions to seek legal redress if they feel aggrieved. Some court cases more especially Abrupt Termination of Employee Contracts in a Democratic State (2011 strike) have soured the relationship between the two parties. Federations of Public Sector Union were derecognized under Ian Khama Presidency in 2017, which adversely impacted on the Public Sector Bargaining Council. In many instances, salary increments were done outside the scope of the Bargaining Council by the government. In this case, more questions than answers were asked by the nation and trade unions about the future of Trade Unions as far as their participation in the bargaining negotiations under the presidency of Ian Khama Seretse Khama. 


\section{AIM OF THE STUDY}

The aim of the paper is to explore how best the government could have done rather than resorting to abrupt Termination of Employee Contracts, due to wage negotiations.

\section{LITERATURE REVIEW}

Fagbemi, (2014) states that in any human relationship, the dispute is inevitable. Once it is inevitable in human relationships, it is not alien to labour relations. The dispute in the labour of relations is more formal than in any other types of relationships. According to Public Service Act (Act No. 30 of 2008) (Cap. 26:01) public officers that willfully breach their employment contract, with the effect that the public is deprived of an essential service, commit a criminal offence in the absence of a credible defence. 'Industrial relations'? (Hyman, 1975) explains that many scholars see the definitions being surprisingly rare, professors and university departments with unquestioned expertise in the field were to seek to specify its nature precisely, and they would be likely to disagree in significant respects. Furthermore, emphasize in their disagreement as to the field is that most writers on industrial relations would agree only in one point " not all social relations in industry fall within their province", hence, the term is not interpreted accurately. Relations in the industry include a vast variety of routine personal interrelationships. In addition to what Hyman, explains

According to (Macneil, J. 2013), Lack of industrial relations (IR) experience or knowledge amongst the negotiating parties both caused and characterized the major 2011 public sector strike in Botswana. Specifically, with no real collective bargaining experience amongst the actors, and little in the way of formal legislative or regulatory guidance, the social processes of creating, interpreting, changing and enforcing the bargaining rules were reactive, evolving, and imperfect.

(Clauwaert, 1992) defines "Essential services" in the strict sense of the term have been defined by the International Labour Organisation as those services "whose interruption would endanger the life, personal safety or health of the whole or part of the population". (Du Toit, \& Ronnie,2012a) explains that a strike may be called provided that: all possibilities under the mandatory procedures for the settlement of disputes have been previously exhausted, a warning strike has taken place and the organisers have informed the employer of the date of the strike at least two working days before the beginning of the strike.

Members of Southern Africa Development Countries (SADC) being (South Africa, Botswana, Lesotho, Namibia, Swaziland, Malawi, Mozambique, Zambia and Zimbabwe) under consideration being regarded as essential services employees are not permissible to engage in national strikes, explains (Le Roux \& Cohen, 
2016)..(Mwatcha, 2015) states that the 2011 public sector strike exposed the frailties of Botswana's industrial relations, a country popularly eulogized as Africa's economic miracle and a shining example of democracy. Furthermore, according to ILO, the right to strike extends to all workers in the public service, the only allowable exception being for employees directly involved in the administration of the state and 'essential services'. Although several countries entrench this right in their constitution, the violation is widespread. In such countries, while the right to strike exists in principle in reality it is essentially curtailed by unworkable procedures, as it is the case in Botswana.

According to (Du Toit \& Ronnie, 2012b) Labour Relations Act sets out to promote "Orderly collective bargaining and the "effective resolution of labour disputes", furthermore, it states that most of the violence strikes in this area, in recent years has cast doubts in the effectiveness of this act. Also, the suggestion is that the government should be able to ban strikes in special circumstances by dismissing, bypassing and in-effect the provision of the act. Also, Democracy has to do with how government, interest group leaders exercise their power-not just their promise to democracy in opinions, but their ability to bargain with one another, form coalitions, mobilize public support and respond to public pressures and preferences (Diamond, 1999).

International Labor Organizations (ILO) (2015) defines Trade Unions as an interest group or organisations joined together so that they have their interests and goals well presented. Also, the Fredriech Ebert Foundations (2003) defines the Trade Union as an organization with principal objects of which include the regulation of relations between employees and employer' organization or between employers and employees. From these definitions one can safely say, Trade Unions Organizations have at the core of their mandate to protect the rights of employees who are registered as their members and this protection of members is in most cases done through the act of bargaining where union representatives and those from the employer engage in social dialogue to improve worker welfare such as good wages and provision of the good working environment.

In a unionized setting, the union considers all the workers while representing them at the bargaining table so that the desires of those who are not likely to leave the enterprise are also represented, this statement is also emphasised by (International Labour Organization, 2015a) that Collective bargaining is necessary as it safeguards that workers who are employed by a firm may not speak out in the fear of being fired and that the collectiveness of trade unions alters the way the labour market operates or functions. Authority \& Board, (2006) states that the parties agree that discussions should occur between employees, Union representatives and Employer representatives when problems or differences arise in an attempt to resolve problems or differences. This grievance procedure is not intended to preclude any discussion between employees, Union representatives and Employer representatives. In simple terms, Collective Bargaining is a give and take process which aims to conclude beneficial to both the parties whereas (International Labour Organization, 
2015b) defines Collective Bargaining as the process by which representatives of management and the unions meet and negotiate over wages, hours and other terms and conditions of employment in good faith

\section{FINDINGS}

The findings show that functionality of Bargaining Council has not been fully utilised as there has been some misunderstanding of union eligibility to sit on the council (whether a certain union meets the threshold required) and the mere fact that the employer part under the presidency of Ian Khama at the time used to make some unilateral announcements on the sensitive matters of public salary increments outside the scope of the bargaining council and this has often created tensions between the union federation ( BOFEPUSU) and the government. Government, employees and Trade Unions do lack training in some dispute issues as they could have stopped the strike before it happened. Conditional wage negotiations between the government and the unions were the cause of strike that took place in 2011 where 3000 essential services workers ended up with their employment Contract terminated abruptly by the government. According to the Trade Dispute Act 2003, Cap 28: 02, (Laws of Botswana), the strike was proper as long as the requisites of lawful strike prescribed bt the Act is met. This section excludes the essential services workers "whose interruption would endanger the life, personal safety or health of the whole or part of the population" as defined by Clauwaert 1999, in the strict sense of the term have been defined by the International Labour Organisation.

\section{DISCUSSIONS}

The massive strike in 2011 was due to conflict between the government, employees and Trade Unions where the government ended up abusing its power. However, due to judicial impartiality, the striking workers were not given the serious challenge for negotiations to be conducted under Botswana Public Service Bargaining Council and tension that arose from disagreement led to disputes that ended up before courts of Law. The creations of federations such as BOFEPUSU and BFTU was meant to unite the government of Botswana with its employees so that their collective voice can compel the employer to see some sense in their demands for improved working conditions and better wages, but under the presidency of Ian Khama, the Public Service Bargaining Council collapsed. The employer was very harsh especially with the abrupt termination of employment contracts of some specific workers "essential Services". In the other hand, the government was inconsiderate, the lives of Batswana were endangered due to insufficient workforce. According to (Armstrong 2009) the government should have handled this case with the principle natural justice and if the employees were facing 
serious disciplinary action such as dismissal as they were in this case, the minimum statutory procedure should be followed such as; a written note to the employee setting out the allegation and the basis for it, a meeting to consider and discuss the situation and a right of appeal including an appeal meeting. In nutshell disciplinary procedures were not followed by the government.

\section{RECOMMENDATIONS}

- Botswana government should respect the tenets of democracy (accountability, transparency and rule of law) when dealing with labour issues to protect her image and integrity.

- All the negotiations that include salary increments and other conditions of service should be conducted under the scope of the Public Sector Bargaining Council.

- Labour laws and acts governing employment and trade disputes should be adhered to by both the government and trade unions to prevent unilateral decisions that are sometimes made by a government that undermines this ACTS.

- Pending issues to be discussed with other stakeholders

\section{CONCLUSION}

Members of Southern Africa Development Countries (SADC) regarded as essential services workers are not permissible to strike. The government acts of unilateralism on making some labour-related issues that needed to be discussed under the scope of a bargaining council weakened the bargaining council itself to a point where it became irrelevant. Mwatcha, (2015) states that the 2011 public sector strike exposed the frailties of Botswana's industrial relations, a country popularly eulogized as Africa's economic miracle and a shining example of democracy. Furthermore, according to ILO, the right to strike extends to all workers in the public service, the only allowable exception being for employees directly involved in the administration of the state and 'essential services'. Although several countries entrench this right in their constitution, the violation is widespread. In such countries, while the right to strike exists in principle in reality it is essentially curtailed by unworkable procedures, as it is the case in Botswana.

The weakening of the bargaining council under Ian Khama presidency weakened the position and ability to engage in social dialogue that can result in a win-win situation for both parties, This, in the long run, hardened the attitudes of both parties towards each other (in addition to the already existing tensions of the industrial strike in 2011 and dismissal of some employees). With the coming presidency of Mokgweetsi Masisi, some consultative meetings were held with trade 
union federation BOFEPUSU, with the president assuring them that the bargaining council which collapsed under the leadership of Ian Khama will be resuscitated and Government of Botswana decided to engage Malaysian company, Performance Management \& Delivery Unit (PEMANDU) Associates to review the public service remuneration and performance systems in a consultancy that would run for 52 weeks beginning December 01, 2017. The company is reportedly well known for its success in transforming the Malaysian economy, and their work, and in particular their Big Fast Result methodology in providing solutions on transforming government in other countries is well documented (Molokwane, 2019). However, the delay of PEMANDU Report has also deepened the mistrust between the two parties. The delay in the resuscitation of the Public Sector Bargaining Council has now put into question the commitment of President Mokgweetsi Masisi promises that he will open doors for social dialogue with trade unions in a bargaining council forum.

From the above statement, one can state that trade union federations which had hoped that bargaining will be conducted under a lawful council body are disappointed that democratic discussion on issues that affect their rank and file are undermined by the government. When it comes to the future of the Public Sector Bargaining Council there seems to be no commitment from the government to resuscitate it. This means trade unions have to seek other strategies that can compel the employer to negotiate in good faith where consultations become key before taking some decisions of the Bargaining Council.this has not materialized as of today there is no functional bargaining council which could have provided a good environment to discuss the recommendations of other issues such as the Performance Management and present PEMANDU Report which made some recommendations on the salary structures of public servants.

\section{References:}

- Authority, M. J. H., \& Board, S. A. (2006). Collective Agreement. Victoria, 2008.

- Batlhalefi Tutwane, L. (2018). Dintwe v the Directorate of Public Service Management and others: when the court suppresses freedom of expression. Commonwealth Law Bulletin, 44(1), 130-153.

- Clauwaert, S. (1992). The right to strike in the public sector. Romania.

- Du Toit, D., \& Ronnie, R. (2012 a, b). The necessary evolution of strike law. Acta Juridica, 195.

- Fagbemi, S. A. (2014). An Overview of the Institutional Mechanisms for the Settlement of Labour Dispute in Nigeria. US-China L. Rev., 11, 1322.

- Fredrich Ebert Foundation (2003). Botswana and its socio-economic dynamics. Africa Labour Report. Munich, Germany.

- Good, K. (2017). Democracy and development in Botswana. Journal of Contemporary African Studies, 35(1), 113-128.

- Hope, K. R. (1995). Managing the public sector in Botswana. International Journal of Public Sector Management.

- Hyman, R. (1975). What is Industrial Relations? In Industrial Relations (pp. 9-31). Palgrave Macmillan, London. 
- International Labour Organization (2015a,b). Best Labour Practices in Africa. Labour Report for the Annual Conference in Geneva. 2015.

- Le Roux, R., \& Cohen, T. (2016). Understanding the Limitations to the Right to Strike in Essential and Public Services in the SADC Region. PER: Potchefstroomse Elektroniese Regsblad, 19(1), 1-25.

- Le Roux, R., \& Cohen, T. (2016). Understanding the Limitations to the Right to Strike in Essential and Public Services in the SADC Region. PER: Potchefstroomse Elektroniese Regsblad, 19(1), 1-25.

- Lekgowe, G. R., \& Botlhole, K. S. (2015). Damages for Wrongful Dismissal in Botswana: High Court and Court of Appeal at Loggerheads. -21 U. Botswana LJ, 20, 3.

- Molokwane, T. (2019). New public management-in Botswana contemporary issues and lessons. African Journal of Public Affairs, 11(1), 48-63.

- Motshegwa, B., \& Bodilenyane, K. (2012). Abrupt termination of employee contracts in a democratic state: the case of Botswana.

- Mwatcha, M. P. (2015). Botswana's labour relations system: lessons from 2011 public sector strike (Doctoral dissertation).

- Public Service Act (Act No. 30 of 2008) (Cap. 26:01).

- Trade Dispute Act 15 of 2004

- Tshukudu, t. t. (2020). the Botswana public sector bargaining council, a reality or fallacy. European Journal of Social Law/Revue Européenne du Droit Social, 47(2). 